\title{
IDENTIFYING CAUSES OF DISPUTES IN CREATIVE INDUSTRIES: LITHUANIAN ARCHITECTURE SEGMENT CASE STUDY
}

\author{
Tomas Mitkus \\ Department of International Economics and Business Management, \\ Vilnius Gediminas Technical University, Sauletekio al. 11, LT-10223 Vilnius, Lithuania \\ E-mail: tomas.mitkus@vgtu.lt
}

\begin{abstract}
Today creative industries are economically efficient, innovative and constantly growing economic segment. On the other hand, creative industry and its unique creative work process, brings increased stress and conflicts possibility to work environment. Causes of conflicts and conflict management have been analyzed in detail by a number of scholars, although conflicts evolving into disputes have been analyzed considerably less often. The causes of disputes in Lithuanian architectural segment were identified and analyzed in this article. These causes were grouped into two main categories - communication and non-communication causes. Case study results show that in $49 \%$ of 107 analyzed cases litigation could have been avoided if communication process between disputes parties would have been conducted professionally throughout all stages of production.
\end{abstract}

Keywords: creative industries, dispute, conflict, construction, architecture, communication.

JEL Classification: M1; K12.

\section{Introduction}

Today creative industries effectively use the synergy of economic efficiency and creativity and easily attract investments, manpower and even induce politicians to start create improved political, legal and taxation conditions for the growth of these industries. Therefore, economic value and creative result (cultural capital) generated by these industries are great motivators for different segments of the creative industries to grow and expand not only in the national but also the international context. And since all creative industries segments (with the exception of fine arts segment) requires teamwork to achieve any results, employment relationships are a natural part of the creative industries. The employment relationships are expressed in the employment contract that defines the responsibilities of the parties. As employment relationships develop between several or more persons, it is natural to expect that during the cooperation established between the parties the conflict will arise simply because conflict exists wherever there is an incompatibility of interest. Conflict can be managed, possibly to the extent of preventing a dispute resulting from the conflict (Cakmak, E., Cakmak, P. I. 2014).

Unregulated conflict among parties related in employment relationships, especially if it transforms into a legal dispute, can become a destructive action to all parties involved (Cheung, Yiu 2006).
This paper seeks to identify, analyze and group the main causes of disputes in creative industries by reviewing court cases of Lithuanian architecture (construction) segment. This investigation is important to improve the management of employment relationships in creative industries and to prevent expensive and destructive litigation process that at its minimum brings negative effect on cost and productivity (Jelodar et al. 2015).

Litigation cases were chosen because judicial ruling allows to collect clear data which determines the causes why conflict rose into the dispute, therefore serious causes of disputes in this segment of creative industries can be identified. This paper analyses and focuses on court cases of only one segment of creative industries - architecture (construction). This segment of creative industries was chosen for very pragmatic reason - every other creative industry segment do not have sufficient court cases to draw any pattern and/or conclusions within 2005-2014 time period in Lithuania.

\section{Assessment of a conflict and dispute manifestation in creative industries}

The 1990s were a period of accelerated globalization which, among other economic segments, created the conditions for creative industries to flourish and today creative industries show not 
only higher than the average indicators in competitiveness, growth, exceptional export, new job creation and performance, but also an abundance of innovations (Blair et al. 2001; Hotho, Champion 2011; Goede, Louisa 2012; De Propris 2013), the creation of a modern cultural "capital" or elevation of social problems and challenges in society (Oxford Economics 2010; EC 2010). It is important to point out that the concept of creative industries, formed in an academic environment in 1990s, immediately emphasized considerable economic value created by creative industries, which naturally but clearly separated them from the cultural industries (the latter are not interested in any commercial returns) (O'Connor 2007; Daubaraite, Startiene 2013). Today creative industries is commonly associated with the generation of products, services, processes or ideas that are (1) novel, and direct result of knowledge and information, and (2) as primarily goal have to provide monetary value (UNCTAD 2004, 2008; Thomassen 2007; Malem 2008; Ashton 2011; Hotho, Champion 2011; Gibbon 2011).

Therefore it is not surprising that today a number of international and local government institutions are willingly trying to create the best possible conditions for the creative industries to emerge (when individual creative industry segments are just starting to settle in), grow (when segments are already formed strong rudiments) or strengthen (in order to provide with an international competitive advantage to the national creative industry segments).

It is also important to note that economic value of the creative industries depends entirely on performance of creativity-driven staff rather than, say, a natural resource of nature, competitive advantage of cheap labor or natural climatic conditions. Therefore, management of human resources becomes one of the most important challenges for creativity driven business in order to create effective teamwork, job satisfaction, efficiency, productivity, motivation, coordination and synergy throughout business units, functions and team members (Zorlu, Hacioğlu 2012). To achieve these objectives it is necessary to properly evaluate and minimize social, cultural, psychological and communicative interferences that may potentially arise in business internally (between staff and different departments) and externally (among business partners, contractors or customers). Once you have an interference (if not identified in a timely manner and are not removed), it leads to conflicts that are emerging as a major obstacle to the successful business model and, as already mentioned above, can be the cause of significant financial losses.

It is interesting to note that conflicts in the creative industries is not widely analyzed and discussed. Because of its production or service specifics creative industries are clearly divided from other economic segments (such as agriculture, heavy industry, culture, public sector, etc.), so separate and thorough management-oriented research is essential. To illustrate the importance of specific tests we should take a glance to Klein and $\mathrm{Lu}$ (Klein, Lu 1990) study, which revealed that roughly $50 \%$ of the statements made by a group of collaborating designers involved either the identification or resolution of conflicts. This data perfectly illustrates the importance of conflict management in creativity-driven teams. Therefore, the development of tools and underlying theories for supporting conflict management in creative industries, as case study results show, could make a vast difference.

Finally, the importance of such studies is that the conflicts have a dire consequences on the relationship quality of the parties involved (Cheung, Yiu 2006), not to mention that emotionally stressful state between the parties may negatively influence their working relationships (Harmon 2003). Moreover, litigation resolution is the most hostile and probably will result in work relationship decline (Fullbright, Jaworski 2006; Podvezko et al. 2010; Mitkus, Sekonaite 2011; Mitkus, S., Mitkus, T. 2014). However, litigation is always the last resort and if other methods for conflict resolutions are ineffective.

\section{Methodology}

A two stage approach was designed to achieve the objectives of the research reported in this paper. Each of two methodology stages is outlined as follows:

- Literature review: In stage 1 relevant articles and research work with the theme of conflict and dispute are identified;

- Review of court cases: Publically available court proceedings and decisions are acquired. With a preliminary review technique data is created. Accordingly information such as the potential causes, numbers of causes, claim nature, entitlement, and dispute triggers are extracted based on court decisions. The results are classified and disseminated via graphs an amalgamated with stage 1 to determine the 
sources of construction dispute. Stage 2 allows for hard evidence to be elicited and incorporated in the research reported in this paper.

\subsection{Literature review}

Is very important to identify and explore the nature of the common causes and triggers of conflict (and dispute) in creative industries, especially since the full awareness and realization of conflicts triggers may be acknowledged only when it is too late to manage without a significant loss of resources and money. Therefore, detection and categorizing the claims will also enable the identification of avoidable causes of claims moreover assisting the settlement of dispute, reducing the damage, time and cost needed for correction (Kumaraswamy 1997).

The studies analyzing the causes of conflict and its regulation in creative industries are uncommon, although the importance of the creative industries and its influence on economic, social and technological development are thoroughly investigated by the international organizations such as UNESCO (2016), UNCTAD (2004, 2008) UNDP, OECD, WTO, World Bank and of course the EU (EC 2010, 2012), not to mention the local authorities - Lithuanian creative industries were studied by the Ministry of Education and Science (LR ŚMM 2008) and the Ministry of Culture (LR KM 2012). The results of studies carried by organizations mentioned above unambiguously indicate creative industries as an important segment of the economy and suggest to enable the most effective conditions for the development of the creative industries.

Therefore, the research of conflict management in creative industries is needed to implement the success of creative industries development.

Academic studies of creative industries detects an internal conflict between "creative" and "industrial" aspects (Lampel et al. 2000; DeFillippi et al. 2007; Potts 2011). The ability to manage creative and economics organizational goals, that are essentially conflictive, has become essential for creative businesses if they are to thrive. Therefore, the ability to adjust emerging conflicts in the team is a necessary condition for a successful business model in today's highly competitive marketplace (Salem, Banner 1992; Pfeffer, Veiga 1999; Alper et al. 2000).

In defining the concept of the conflict, many scholars believe, that the nature of conflict is related to ethnicity, cross cultural disputes, religious differences and socio economic inequality (Balkenohl
1971; Mitroff, Emshaff 1979; Wall, Nolan 1986; Litterer 1996; Robbins 1998; Bennett 2002; Jehn, Bendersky 2003; Fial et al. 2009). Fenn et al. (1997) compared conflict to a disease - it exists if there is a conflict between the interests, regardless of whether there is a claim or not.

Meanwhile in business sector conflict is usually characterized in terms of the range, the scope and intensity of disagreements that arise among firms. These disagreements stem from various sources: from the goal divergence of firms, differing perceptions of reality, domain dissensus - that is, disagreements over roles - and from communication problems (Rosenbloom 1999).

Properly managed conflict can improve group outcomes (Rahim, Bonoma 1979; Alper et al. 2000; Kuhn, Poole 2000; DeChurch, Marks 2001; Lakis 2008). But more statistically realistic outcome of conflict is that it can create a destructive effect - reduces the effectiveness of the production (creative), the implementation of the project requires additional (unforeseen) resources, deteriorating labor environment, increased staff turnover or the loss of partners and customers and, in some cases, even litigation.

Many authors studying disputes in the segment of architecture (Hewitt 1991; Diekmann et al. 1994; Heath et al. 1994; Rhys-Jones 1994; Semple et al. 1994; Bristow, Vasilopoulos 1995; Colin et al. 1996; Sykes 1996; Kumaraswamy 1997; Mitropoulos, Howell 2001; Acharya, Lee 2006; Blake Dawson Waldron 2006; Cheung, Yiu 2006; Yiu, Cheung 2007) believe that the most effective way to settle the conflict is by identifying and codifying the main catalysts of conflict (such as people, products, processes, etc.). But there are doubts on feasibility in reviewed literature sources of conflict in the construction, because determining the cause of conflict in the construction authors actually used just one main study method - the survey of participants in construction, and also expressed their subjective opinion of the relevant issue (Mitkus, S., Mitkus, T. 2014). In current scientific literature, externally visible circumstances of conflicts in architecture (delays, incompetence of workers, unpredictable factors of nature, etc.) are often referred to as the causes of conflicts. Meanwhile the real causes of conflict are the failure of communication between the parties of the construction contract. It is necessary to mention that vaguely prepared construction contract prevents from the settlement of conflicts (communication product), since the lack of ability to unambiguously determine which party bears the responsibility to assume the losses due to various 
unforeseen circumstances, the conflict takes excellent conditions turn into a dispute.

A lot of studies have considered that dispute is a separate phenomenon evolving from the conflict, and the main exclusiveness of it is that the parties of the conflict cannot withdraw unilaterally and dispute is usually resolved by arbitration or court (Diekmann, Nelon 1985; Hewitt 1991; Semple et al. 1994; Heath et al. 1994; Kumaraswamy 1997; Acharya, Lee 2006; Mitkus, S., Mitkus, T. 2014).

The author in this paper will follow a broad approach that the conflict between business relationships with individuals in the most general sense is a disagreement, and if the conflict is rampant, it creates different kinds of negative consequences. When the parties of the conflict can no longer self-regulate the conflict and appeal to the court, the conflict develops into a legal dispute.

\subsection{Review of court cases}

The primary source of data for this stage of research reported in this paper was obtained from Infolex - online search system of Lithuanian court cases. A total of 449 cases of architecture (construction) dispute were identified through the period of 2005-2014. After an initial investigation all court decisions of first instance (district courts and regional courts) and second instance (The Court of Appeal) were removed due to fact that only $51 \%$ of winning parties remain the same in the final court order and only in $30 \%$ of cases the final court order remain the same in all three instance courts. Therefore, analysis of final court order before it reaches the highest (the $3^{\text {rd }}$ ) instance (The Supreme Court of Lithuania) is not appropriate for a statistically huge probability of changes in the final court decisions. The study aims to identify the cause of the conflict, rather than a cause of winning. Consequently 107 court decisions from the highest (the $3^{\text {rd }}$ ) instance (The Supreme Court of Lithuania) were acceptable for the research reported in this paper.

This data extracting framework basically involves the following steps:

- Information such as claim amount, dates, and parties;

- Documenting court decisions of all three instance courts;

- Identifying events or causes that triggered conflict based on information presented court orders;

- Information is categorized and documented.

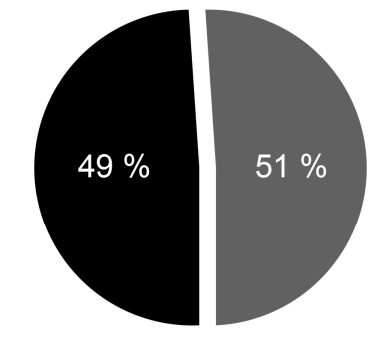

COMMUNICATION BASED DISPUTES

NON-COMMUNICATION BASED DISPUTES

Fig. 1. Division between causes of the disputes analysed in court decisions (Source: author)

The study identified two main causes of disputes: communication and non-communication (Fig. 1).

Non-communication based disputes arise when (1) client fails to pay for the work $-30.84 \%$; (2) contractor (or subcontractor) does not fulfil its obligations (to eliminate defects during the warranty period, the contractor fails to perform the work on time, etc.) $-11.2 \%$; (3) contractor has unreasonable requirements $-5.6 \%$ or (4) client has unreasonable requirements $-4.67 \%$. As seen from the information provided in the table (Fig. 3) customers who for various reasons refused to pay contractual remuneration for the work carried out and/or building materials are mostly responsible for non-communication disputes. Almost the third (31\%) of all highest instance court decisions are related with client's refusal to pay for construction work or building materials.

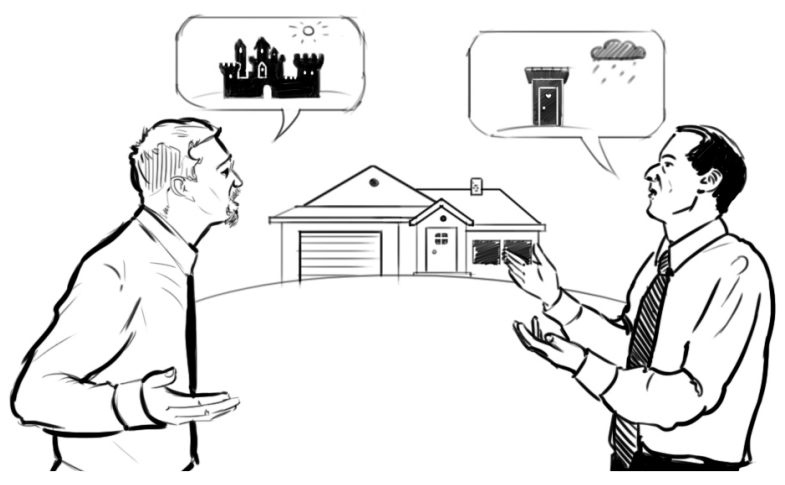

Fig. 2. Improper communication - the key to failure (Source: author)

To avoid non-communication based disputes is practically impossible, but it is possible and necessary to prepare for this type of conflict - appropriate contracts, mortgages, guarantees, orderly completion of documentation, appropriate communication while performing of the contract. 

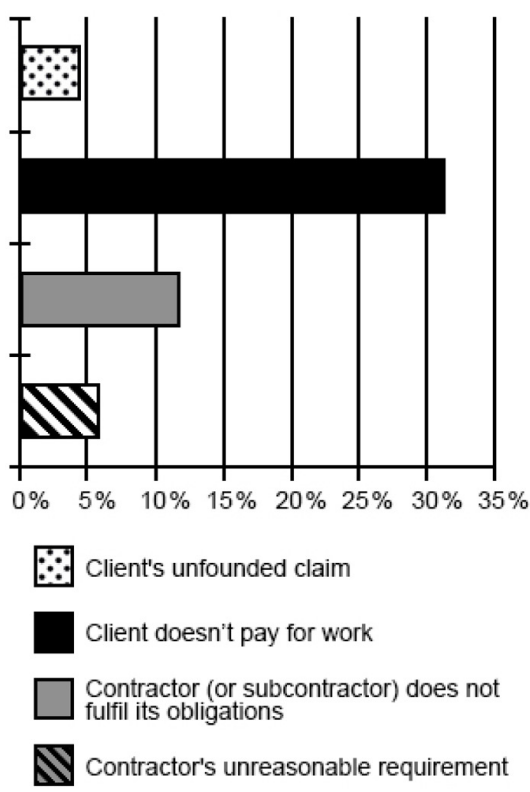

Fig. 3. The causes of non-communication based disputes (Source: author)

Communication based disputes arises when parties for various reasons have different interpretations of the draft law or contract procedures. Moreover, the parties may present unreasonable demands and unlike in non-communication based disputes are convinced of their righteousness (Fig. 2).

As shown in the chart (Fig. 4) the causes of communication based disputes are: (1) differently interpreted terms of the contract $-72.55 \%$; (2) differently interpreted laws - $13.73 \%$; (3) poor communication during the pre-contractual period $7.84 \%$; (4) inappropriate communication while performing contractual commitments $-3.92 \%$ and finally (5) improperly entered data or finalized documents $-1.96 \%$.

It is possible to avoid communication-based disputes.

\section{Findings}

The study identified that the main causes of disputes are divided between two: communication based and non-communication based causes. It should be noted that in an ideal world disputes take place only under the following conditions:

- Litigation should arise only in cases where at least one party intentionally fails to fulfil its obligations;

- Parties whose interests have been violated should be able to easily prove the legitimacy of losses;

- The courts of all instances provided with the same data should adopt the same decisions.
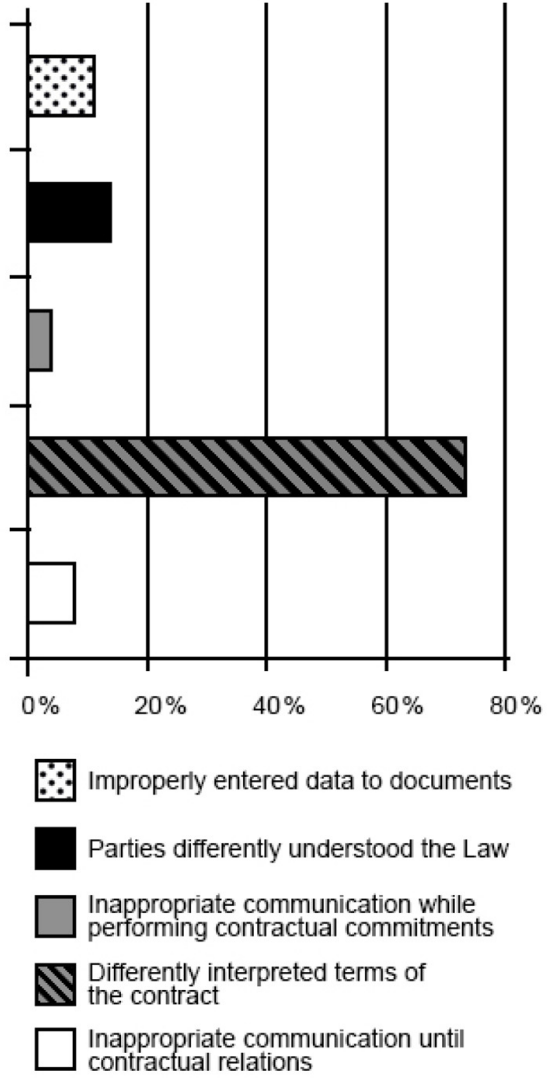

Fig. 4. The causes of communication based disputes (Source: author)

However, studies have revealed that the real situation is not idyllic. The fact, that almost half disputes are communication based is unthinkable and rises a huge problem, especially considering the fact that communication based disputes could be avoided.

Conducted study suggests, that today a large number of parties with in business relationship do not value the contract as the main pillar defining their working relationship and the primary source of determining which party (consciously or unconsciously) violated the agreement.

Fledgling practice to strictly and competently identify and capture work relations in a contract (rather than verbal) could be considered as a delayed bomb which becomes destructive force and no longer allows to regulate the conflict and it turns into a dispute.

Almost 14\% of communication based disputes arose from differently perceived provisions of the law. Court orders do not specify the legal education level of the parties and if parties were even aware of the specific law that they wrongly interpreted, however, the court claims show that very often the parties are so convinced of their own righteousness, that they even believe that the law has to prove they righteousness by default. There- 
fore, when party convinced of its own righteousness takes actions that are not legit, the court, often have no choice but to pledge not guilty the party that took legal actions and was able to prove in court the losses caused by the opposing party previous actions. The rule of law suggests that any party of the dispute should take legal aid from qualified lawyers and not to rely on their own legal knowledge. Actions based only on believe of one's righteousness do not bear weight of objective facts. This could be an indirect partly solution to prevent communication based disputes.

The study also revealed that $16 \%$ of all cases arose in terms of miscommunication in determining the volume of construction work and prices. It is a significant amount taking in consideration the fact that the volume and prices of construction work should be discussed first and prioritized in negotiation and signing the contract. Data illustrates that parties sometimes do not consistently describe the scope of work and prices in the contract and often are assuming that in case of the conflict exclusively their needs will be considered a priority.

\section{Conclusions}

All the segments of creative industries produce a complex and competitive environment in which participants with different views, talents and levels of skills and knowledge of the production process work together. Since differences in perceptions exist among the participants of the projects conflicts are inevitable in the architecture industry (Cakmak, E., Cakmak, P. I. 2014). Unmanaged conflicts in the business sector can and often evolve into dispute - phase, which is destructive to all parties of the dispute and there is no unambiguous winner (Jelodar et al. 2015).

This paper presents these results of court cases study in the field of architecture (construction):

- Almost half of all investigated cases (49\%) in Lithuania were caused by communication problems and conflict evolution to the dispute could have been avoided.

- Significant number of communication based disputes was caused by different interpretations of the contract $(72.55 \%$ of all communication based disputes). It shows that parties do not consider the contract as the main document defining most important conditions, commitments and responsibilities. Vague contracts not only turns the conflict into dispute, but also complicate the judicial process, because it becomes difficult to determine the true culprit.
- Before entering any business related relationship parties must rely on competent legal advice in preparing the contract. Analyzed court cases revealed that in some disputes parties not only agreed on vaguely described (construction) object, but in contract even had contradicting provisions.

- It is impossible to avoid non-communication based disputes but it is necessary to take all measures to ensure that in case of this kind of dispute all losses would be compensated.

Creative industries by its nature will always be a suitable field for conflicts to emerge and evolve. Therefore, the most successful management strategy is not to try avoid conflict in general, but to provide the widest possible tools in the contract to allow a rapid and effective resolution of the conflict.

\section{References}

Acharya, N. K.; Lee, Y. D. 2006. Conflicting factors in construction projects: Korean perspective, Construction and Architectural Management 13(6): 543-566. http://dx.doi.org/10.1108/09699980610712364

Alper, S.; Tjosvold, D.; Law, K. S. 2000. Conflict management, efficacy, and performance in organizational teams, Personnel Psychology 53: 625-642.

http://dx.doi.org/10.1111/j.1744-6570.2000.tb00216.x

Ashton, D. 2011. Media work and the creative industries. Identity work, professionalism and employability, Education + Training 53(6): 546-560. http://dx.doi.org/10.1108/00400911111159494

Balkenohl, M. 1971. The origin of psychic disturbances and interhuman conflicts: an anthropological enlighteming og personeal relations, Heilpaedagogik 40: $174-179$.

Bennett, J. 2002. Multicultural corporations, social responsibility and conflict, Journal of International Affairs 55(2): 393-410.

Blair, H.; Grey, S.; Randle, K. 2001. Working in film. Employment in a project based industry, Personnel Review 30(2): 170-185. http://dx.doi.org/10.1108/00483480110380334

Blake Dawson Waldron. 2006. Scope for improvement: a survey of pressure points in Australian construction and infrastructure projects [online]. A Report Prepared for the Australian Constructors Association, Blake Dawson Waldron, Sydney [cited 22 February 2016]. Available from Internet: http://www.constructors.com.au/wp-content/ uploads/2006/06/ACA_Scope_for_Improvement 2006.pdf

Bristow, D.; Vasilopoulos, R. 1995. The new CCDC 2: facilitating dispute resolution of construction projects, Construction Law Journal 11(2): 95-117. 
Cakmak, E.; Cakmak, P. I. 2014. An analysis of causes of disputes in the construction industry using analytical network process, in $2^{\text {nd }}$ World Conference On Business, Economics And Management, 25-28 April 2013, Antalya, Turkey, 183-187. http://dx.doi.org/10.1016/j.sbspro.2013.12.441

Cheung, S. O.; Yiu, T. W. 2006. Are construction disputes inevitable?, IEEE Transactions on Engineering Management 53(3): 456-470. http://dx.doi.org/10.1109/TEM.2006.877445

Colin, J.; Langford, D.; Kennedy, P. 1996. The relationship between construction procurement strategies and construction contract conflicts, in International Symposium of the CIB W-92 on Procurement, 14-16 January 1996, Durban, South Africa.

Daubaraite, U.; Startiene, G. 2013. Creative industries impact on national economy in regard to subsectors, in $20^{\text {th }}$ International Scientific Conference Economics and Management, 6-8 May 2015, Kaunas, Lithuania, 129-134.

De Propris, L. 2013. How are the creative industries weathering the crisis?, Cambridge Journal of Regions, Economy and Society 6: 23-35. http://dx.doi.org/10.1093/cjres/rss025

DeChurch, L. A.; Marks, M. A. 2001. Maximizing the benefits of task conflict: the role of conflict management, The International Journal of Conflict Management 12: 4-22. http://dx.doi.org/10.1108/eb022847

DeFillippi, R.; Grabher, G.; Jones, C. 2007. Introduction to paradoxes of creativity: managerial and organizational challenges in the cultural economy, Journal of Organizational Behavior 28: 511-521. http://dx.doi.org/10.1002/job.466

Diekmann, J. E.; Girard, M. J.; Abdul-Hadi, N. 1994. Dispute potential index: a study into the predictability of contract disputes. Construction Industry Institute, Boulder. http://dx.doi.org/10.1061/ (ASCE)0733-9364(1985)111:1(74)

Diekmann, J. E.; Nelon, M. C. 1985. Construction claims: frequency and severity, Journal of Construction Engineering and Management 111(1): 74-81.

EC. 2010. Unlocking the potential of cultural and creative industries [online]. Green Paper [cited 22 February 2016]. Available from Internet: http://eur-lex.europa.eu/legal-content/EN/TXT/ ?uri $=$ celex:52010DC0183

EC. 2012. Communication from the Commission to the European Parliament, the Council, the European Economical Social Committee and the Committee of the Regions - Promoting cultural and creative sectors for growth and jobs in the EU [online]. Green Paper [cited 22 February 2016]. Available from Internet:

http://www.europarl.europa.eu/registre/docs_autre s_institutions/commission_europeenne/com/2012/ 0537/COM_COM\%282012\%290537_EN.pdf
Fenn, P.; Lowe, D.; Speck, C. 1997. Conflict and dispute in construction, Construction Management and Economic 15 (6): 513-518.

http://dx.doi.org/10.1080/014461997372719

Fial, C.; Pratt, M. G.; O’Connor, E. J. 2009. Managing interactable identity conflicts, Academy of Management Review 34(1): 32-55. http://dx.doi.org/10.5465/AMR.2009.35713276

Fulbright, R. C.; Jaworski, L. L. P. 2006. The third annual report of the litigation trends survey findings [online], [cited 22 February 2016]. Available from Internet: http://adrresources.com/docs/adr/22-2188/informe-fulbright-2010-fulbright-jaworskilitigation-survey.pdf

Gibbon, Ch. 2011. How much can the creative industries contribute to regional development in Britain? [online], [cited 22 February 2016]. Available from Internet: http://www.regionalstudies.org/ uploads/funding/conferences/presentations/ international-conference-2011/gibbon.pdf

Goede, M.; Louisa, G. 2012. A case study of the creative zone Scharloo and Pietermaai in Curacao, International Journal of Social Economics 39(11): 844-858.

http://dx.doi.org/10.1108/03068291211263899

Harmon, K. 2003. Effectiveness of dispute review boards, Journal of Construction Engineering and Management 129(6): 674-679. http://dx.doi.org/ 10.1061/(ASCE)0733-9364(2003)129:6(674)

Heath, B.; Hills, B.; Berry, M. 1994. The origin of conflict within the construction process. CIB Publication 171, First Plenary Meeting of TG-15, The Netherlands.

Hewitt, J. 1991. Winning construction disputes: strategic planning for major litigation. Ernst and Young, London.

Hotho, S.; Champion, K. 2011. Small businesses in the new creative industries: Innovation as a people management challenge, Management Decision 49(1): 29-54.

http://dx.doi.org/10.1108/00251741111094428

Jehn, K.; Bendersky, C. 2003. Intragroup conflict in organizations, Research in Organizational Behavior 25: 187-242.

http://dx.doi.org/10.1016/S0191-3085(03)25005-X

Jelodar, M. B.; Yiu, T. W.; Wilkinson, S. 2015. Systematic representation of relationship quality in conflict and dispute: for construction projects, Construction Economics and Building 15(1): 89-103. http://dx.doi.org/10.5130/ajceb.v15i1.4281

Klein, M.; Lu, S. C. Y. 1990. Conflict resolution in cooperative design, International Journal for Artificial Intelligence in Engineering 4(4): 168-180. http://dx.doi.org/10.1016/0954-1810(89)90013-7

Kuhn, T.; Poole, M. S. 2000. Do conflict management styles affect group decision making?, Human Communication Research 26: 558-590.

http://dx.doi.org/10.1111/j.1468-2958.2000.tb00769.x 
Kumaraswamy, M. 1997. Conflicts, claims and disputes, Engineering, Construction and Architectural Management 4(2): 95-111.

http://dx.doi.org/10.1108/eb021042

Lakis, J. 2008. Conflict resolution and management. Vilnius: Mykolas Romeris University publishing center.

Lampel, J.; Lant, T.; Shamsie, J. 2000. Balancing act: learning from organizing practices in cultural industries, Organization Science 11(3): 263-269. http://dx.doi.org/10.1287/orsc.11.3.263.12503

Litterer, J. A. 1996. Conflict in organization: a reexamination, Academy of Management Journal 9(3): 178-186. http://dx.doi.org/10.2307/255117

LR KM. 2012. Creative industries - Lithuania's productive part of the economy. A study. Ministry of Culture, Vilnius.

LR ŠMM. 2008. Integrated national arts, science, education and business complex program "Lithuanian creative and cultural industries". A feasibility study. Ministry of Education and science, Vilnius.

Malem, W. 2008. Fashion designers as business: London, Journal of Fashion Management and Marketing 12(3): 398-414.

http://dx.doi.org/10.1108/13612020810889335

Mitkus, S.; Mitkus, T. 2014. Causes of conflicts in a construction industry: a communicational approach, in $2^{\text {nd }}$ International Scientific Conference Contemporary Issues in Business, Management and Education '2013, 14-15 November 2013, Vilnius Lithuania, 777-786.

http://dx.doi.org/10.1016/j.sbspro.2013.12.922

Mitkus, S.; Sekonaite, A. 2011. Liability of construction participants for delays, Business, Management and Education 9(1): 140-156.

Mitroff, I.; Emshaff, J. 1979. On strategic assumptionmaking: a dialectical approach to policy and planning, Academy of Management Review 4(1): 1-12.

Mitropoulos, P.; Howell, G. 2001. Model for understanding preventing and resolving project disputes, Journal of Construction, Engineering and Management 127(3): 223-231. http://dx.doi.org/10. 1061/(ASCE)0733-9364(2001)127:3(223)

O'Connor, J. 2007. The cultural and creative industries: a review of the literature. A report for creative partnerships. London: Arts Council.

Oxford Economics. 2010. The Economics Impact of the UK Film Industry. Oxford: Oxford Economics.

Pfeffer, J.; Veiga, J. F. 1999. Putting people first for organizational success, Academy of Management Executive 13(2): 37-48.

http://dx.doi.org/10.5465/ame.1999.1899547

Podvezko, V.; Mitkus, S.; Trinkūnienè, E. 2010. Complex evaluation of contracts for construction, Journal of Civil Engineering and Management 16(2): 287-297. http://dx.doi.org/10.3846/jcem.2010.33
Potts, J. 2011. Creative industries and economic evolution. Cheltenham: Edward Elgar Publishing Limited. http://dx.doi.org/10.4337/9780857930705

Rahim, M. A.; Bonoma, T. V. 1979. Managing organizational conflict: a model for diagnosis and intervention, Psychological Reports 44: 1323-1344. http://dx.doi.org/10.2466/pr0.1979.44.3c.1323

Rhys-Jones, S. 1994. How constructive is construction law?, Construction Law Journal 10(1): 28-38.

Robbins, S. P. 1998. Organizational Behavior concepts, controversies, and applications. $8^{\text {th }} \mathrm{ed}$. Upper Saddle River, NJ: Prentice Hall.

Rosenbloom, B. 1999. Distribution channels. Fort Worth: Dryden Press.

Salem, M. A.; Banner, D. K. 1992. Self-managing work teams: an international perspective, Leadership \& Organization Development Journal 13(7): 3-8. http://dx.doi.org/10.1108/01437739210022847

Semple, C.; Hartman, F.; Jergeas, G. 1994. Construction claims and disputes: causes and cost/time overruns, Journal of Construction, Engineering and Management 120(4): 785-795. http://dx.doi.org/ 10.1061/(ASCE)0733-9364(1994)120:4(785)

Sykes, J. 1996. Claims and disputes in construction, Construction Law Journal 12(1): 3-13.

Thomassen, A. 2007. Design of the netgeneration: streaming the flow of design and science in the educational practice of the creative industry, Kybernetes 36(9): 1529-1542.

UNCTAD. 2004. Creative industries and development [online]. TD (XI)/BP/13 [cited 22 February 2016]. Available from Internet:

http://www.unctad.org/en/docs/tdxibpd13_en.pdf

UNCTAD. 2008. Creative economy: the challenge of assessing the creative economy: towards informed policy-making [online]. A Creative Economy report [cited 22 February 2016]. Available from Internet: http://unctad.org/en/docs/ditc20082cer_en.pdf

UNESCO. 2016. A platform to collect and compare cultural statistics globally [online]. United Nations Educational, Scientific and Cultural Organization. UNESCO Institute for Statistics [cited 22 February 2016]. Available from Internet: http://www.uis. unesco.org/culture/Pages/default.aspx

Wall, V.; Nolan, L. 1986. Perception of inequality, satisfaction, and conflict in task oriented groups, $\mathrm{Hu}$ man Relations (39): 1033-1052. http://dx.doi.org/10.1177/001872678603901106

Yiu, T. W.; Cheung, S. O. 2007. Behavioral transition: a framework for construction conflict-tension relationships, IEEE Transactions on Engineering Management 54(3): 498-505. http://dx.doi.org/10.1109/TEM.2007.900784

Zorlu, K.; Hacioğlu, Ü. 2012. The conflict issue in international business and the global leadership, in $1^{\text {st }}$ International Conference on Leadership, Technology and Innovation Management, 21-23 October 2011, Antalya, Turkey, 100-107. 